\title{
THE DEFICIENT ROLE OF LATIN AMERICA IN REGULATION OF CRYPTOCURRENCY
}

\author{
Juan Emmanuel Delva \\ Benavides*, \\ Alondra Guadalupe Mora \\ Hernández
}

University Center of Economic and Administrative Sciences, University of Guadalajara, Jalisco, Mexico

\section{Correspondence:}

Juan Emmanuel Delva Benavides

e-mail:

emmanueldelva@gmail.com

\begin{abstract}
:
The inherent changes brought by the implementation of technology in everyday life have repercussions in all areas, one of them, to mention a few among the most significant, is in the financial market, which it is among the most regulated sectors by both national governments and international entities. However, the recent operations carried out with assets other than those traditionally known that involve the use of technological tools cause a confusion regarding the reliability of the same given the lack of support from any regulatory entity. The actions that have been implemented by some governments, especially from developed countries, demonstrate the deficiencies that legislation can have on certain occasions. While only a few Latin American countries present initiatives, as well as almost no activity in this regard in a market that is increasing worldwide.
\end{abstract}

\section{Keywords:}

Cryptocurrency, Blockchain, Regulation, Legislation.

\section{INTRODUCTION}

The multiple shocks that the world economy has experienced during the last thirty years are due in large part to the monetary and financial regulations set forth by the authorities represented as the set of State bodies that are responsible for the fundamental decisions in pecuniary and financial matters, as well as its execution, they have not been oriented to face disagreements and they are characterized by the absence of international cooperation. This results from the fact that, at present, one of the main risks faced by the international monetary system is the automation of the global financial market [1]. In the contemporary environment, the economy is conceived as part of a global village, where the supports, currency and means of account created by computer mechanisms that interoperate in a network favor the elimination of barriers between societies [2]. The revolution generated by ITs refers to the tools to manipulate, organize, process, transform, transmit and store information in a digital way. This revolution has emerged and spread with greater speed and breadth in the economy than previous technological revolutions [3]. The digital market is an instrument free for geographical ties that accommodates other forms of mores mobile and less material money adopting an electronic, virtual and digital support based on the possibility of a 
technological advanced economy where transactions are carried out by accessing an account system. One of these means is digital currencies, whose control is recognized by an online commercial circuit and its recognition is decentralized since it does not have the backing of any Central Bank. Within digital currencies are differentiated those based on cryptographic techniques that describe the transmission of data called cryptocurrencies, including Bitcoin, Dash, Ethereum, Ripple and Litecoin to mention some of the 1,300 different types that exist. The emergence of cryptocurrencies occurs as a result of the crisis during 2008 that had its beginnings in the United States due to failures in economic regulation, crimes committed by banks, a more competitive world market, energy crisis and the possibility of a recession around the world which produced a credit crisis, mortgage and distrust in all markets [4].

\section{RESULTS AND DISCUSSION}

\section{Market Capitalization 2017}

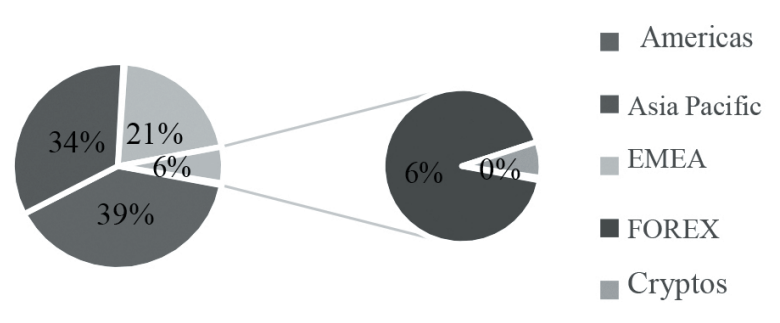

Fig. 1. Percentaje of Market Capitalization in 2017 Source: [5], [6] \& [7].

\begin{tabular}{lcc}
\hline $\begin{array}{c}\text { Market } \\
\text { Capitalization }\end{array}$ & USD Million & $\begin{array}{c}\text { Market } \\
\text { Percentage }\end{array}$ \\
\hline Americas & $\$ 36,486,328$ & $39.36 \%$ \\
\hline Asia Pacific & $\$ 31,266,014$ & $33.72 \%$ \\
\hline EMEA & $\$ 19,409,417$ & $20.94 \%$ \\
\hline FOREX & $\$ 5,100,000$ & $5.50 \%$ \\
\hline Crypto & $\$ 448,436$ & $0.48 \%$ \\
\hline
\end{tabular}

Table 1. World markets capitalization

\begin{tabular}{|c|c|c|}
\hline Criptocurrency & Price & $\begin{array}{c}\text { Percentage of } \\
\text { Variation }\end{array}$ \\
\hline BTC & $\begin{array}{l}\text { April } 282013 \text { - } \\
\$ 135.30 \text { USD } \\
\text { Feb } 202018 \text { - } \\
\$ 11,403.70 \text { USD }\end{array}$ & $+8328.45 \%$ \\
\hline ETH & $\begin{array}{l}\text { August } 072015 \text { - } \\
\$ 2.77 \text { USD } \\
\text { February } 202018 \text { - } \\
\$ 895.37 \text { USD }\end{array}$ & $+32,223.82 \%$ \\
\hline LTC & $\begin{array}{l}\text { April } 282013 \text { - } \\
\$ 4.35 \text { USD } \\
\text { February } 202018 \text { - } \\
\$ 232.85 \text { USD }\end{array}$ & $+5,252.87 \%$ \\
\hline$X R P$ & $\begin{array}{l}\text { August } 042013 \text { - } \\
\$ 0.005882 \text { USD } \\
\text { February } 202018 \\
\text { - \$1.09 USD }\end{array}$ & $+18,431.11 \%$ \\
\hline$A D A$ & $\begin{array}{l}\text { October } 012017 \text { - } \\
\$ 0.024970 \text { USD } \\
\text { February } 202018 \text { - } \\
\$ 0.378779 \text { USD }\end{array}$ & $+1,416.93 \%$ \\
\hline
\end{tabular}

Table 2. Variation percentaje of different cryptocurrencies since they were listed in the cryptocurrency market capitalization.

The financial system is currently preparing for the inclusion of cryptocurrencies as a fundamental part of the global economy and digital finance since their value has increased exponentially. This despite the remarkable observations about its constant fluctuation and its positioning as an unreliable mean of payment and transaction, However, its consolidation with the passage of time and continuous growth has given rise to acceptance by international organizations, companies and investors, becoming a notable reference in the financial system.

One of the main economic difficulties faced by emerging countries, including Latin American nations, is the difficulty in obtaining currency and accessing international debt markets at reasonable prices, which is why the use of cryptocurrencies represents a new kind of fiduciary money by serving as a unit of account and reserve of value [8]. 


\section{BLOCKCHAIN AND CRIPTOCURRENCY}

Blockchain is an incorruptible digital book of economic transactions that can be programmed to record not only financial transactions, but virtually everything that has value [9].

The value and quantity of digital currencies is not regulated by any monetary authority of any country [10], but they are regulated by an encryption process, that is, the codification of information to protect it against third parties [11], the control of transactions, where the cryptocurrencies are represented, is carried by Blockchain [12]. This functions as a free source code through the P2P (Peer to Peer) model, in this way the price is determined by supply and demand.

The power of Blockchain comes from the conjunction of its three great qualities: it is irrefutable, irrevocable and well distributed. This technology is based on four foundations: the shared registry of transactions (ledger), the consensus to verify transactions, a contract that determines the operating rules of transactions and cryptography [13].

Fintech is a term used to describe companies that operate in the financial technology sector. It refers mainly to small start-ups that develop innovative technology solutions in areas such as online and mobile payments, big data, alternative finance and financial management
[14]. The Fintech sector is promoting financial inclusion by generating solutions to the credit rating in a different way to the standard, with users who are not banked, who are informal and who are difficult to access or of which there is no key information according to the classic parameters of evaluation [15].

There are two opposing tendencies around regulation, the centralization supported by international organizations that promote this ordinance and the decentralization that relies on The Internet and information technologies, taking as a reference that the history of money as social technology shows that the decentralization and the absence of an initial regulation brought with it recurrent problems and led to a subsequent crisis of all the involved actors, as a result the legislation benefited everyone.

Currently, cryptocurrencies have developed a variety of interesting projects with application in everyday life that make use of Blockchain technology. It is important to note that in many cases the project is what makes it acquire value.

By allowing digital information to be distributed, but not copied, Blockchain technology created the backbone of a new type of internet. Originally designed for the digital currency, Bitcoin, the tech community is now finding other potential uses for this technology [16].

\section{Cryptocurrency}

File storage platform that takes advantage of the token of Siacoin, smart SC contracts and blockchain technology to store data securely on hosts distributed around the world.

Digital asset that uses Blockchain STEEM technology to build a decentralized network of publications and comments

Decentralized platform that executes intelligent contracts: applications that run exactly as they are programmed without the possibility of downtime, censorship, fraud or interference from third parties.

\section{Description}

Contracts of storage define the conditions under which a storage provider maintains user data and require the provider to periodically submit storage tests to ensure the customer that the data is in good hands. These contracts are stored in the block chain so that they are publicly auditable.

Steemit takes advantage of Blockchain technology to reward in a fair, decentralized, balanced and sustainable way to its users through its currency: Steem. When content is generated, people vote for you and your publication generates a value; $50 \%$ of said value will be "consumable" money and the other $50 \%$ will be voting power. It is a form of feedback that encourages users to remain active members.

The applications are executed in a chain of customized blocks, a shared global infrastructure that can move the value and represent ownership of the property. This allows developers to create markets, store records of debts or promises, move funds according to instructions given in the past (such as a will or a futures contract) and many other things that have not yet been invented, all without intermediaries or counterparty risks. 
Basic token of attention, it radically improves the efficiency of digital advertising by creating a new token $B A T$ that can be exchanged between publishers, advertisers and users. Everything happens in the chain of values not estimated Ethereum blockchain.

Blockchain start-up based in the United Kingdom that offers a platform aimed at financial institutions and other corporations that want to create commercial solutions using blockchain technology.
The token can be used to obtain a variety of advertising and attention services on the Brave platform. The token's utility is based on the user's attention, which simply means a person's focused mental commitment.

It allows companies to create custom blockchain applications using, among other aspects, Microsoft's. Net framework. In addition, companies can create their own private blockchains (sidechains) using Stratis that can be accessed through APIs and lite clients. All private blockchains are secured in the main Stratis chain.

Tabla 3. Application description of some cryptocurrencies with blockchain technology

\section{REFERENCE OF REGULATION IN THE COUNTRIES}

\begin{tabular}{|c|c|c|}
\hline Country & Measures & Advances in Legislation \\
\hline China & $\begin{array}{l}\text { Activities related to the handling of } \\
\text { cryptocurrencies in exchange houses } \\
\text { are prohibited }\end{array}$ & $\begin{array}{l}\text { Measures against the cryptocurrency trade are intensified fo- } \\
\text { cusing on platforms and exchange applications [17]. }\end{array}$ \\
\hline Switzerland & $\begin{array}{l}\text { It publishes guidelines that will gov- } \\
\text { ern ICOs within the country, based } \\
\text { on current legislation for the financial } \\
\text { market. }\end{array}$ & $\begin{array}{l}\text { Three token categories are recognized that depend on the } \\
\text { function and their transferability. }\end{array}$ \\
\hline United States & $\begin{array}{l}\text { The Commodity Futures Trading } \\
\text { Commission and the Securities and } \\
\text { Exchange Commission alert the cryp- } \\
\text { tocurrency companies about the need } \\
\text { for regulation [18]. } \\
\text { Approves Bill to Release Taxes on } \\
\text { Cryptocurrency Holdings in the State } \\
\text { of Wyoming. }\end{array}$ & $\begin{array}{l}\text { Observing more closely the operation of initial offers and ex- } \\
\text { erting pressure on the self-regulation of issuing entities. } \\
\text { Positioning in a same status, at least in terms of tax collection, } \\
\text { to fiduciary money and cryptocurrencies. }\end{array}$ \\
\hline France & $\begin{array}{l}\text { The trading of unlisted values using } \\
\text { Blockchain, eliminating the action of } \\
\text { intermediaries [19]. }\end{array}$ & $\begin{array}{l}\text { Preparation of the Franco-German initiative where a proposal } \\
\text { is made about legislation that reduces the risks of using cryp- } \\
\text { tocurrencies [20]. }\end{array}$ \\
\hline Venezuela & $\begin{array}{l}\text { Publishes the License Acquisition } \\
\text { Manual for the houses of Venezuelan } \\
\text { cryptocurrency }\end{array}$ & Regulates the activity of the houses of cryptocurrency exchange. \\
\hline
\end{tabular}

Table 4. Advances in cryptocurrency legislation

In Latin America, government institutions remain somewhat immutable before the issue of the implementation of cryptocurrencies that today is a global issue and that has a significant impact on the region, the private sector further evidence the inertia of the states given the high initiative that they present in this matter. In 2016, a proposal that could be represented as an indication of regulation in Latin America is developed in Mexico, which is called the Financial Technology Law (Fintech Law), which encompasses various sectors such as electronic payment funding and crowdfunding, as well as operations with virtual assets [21]. Despite its approval, a position of uncertainty has been generated, due to the fact that, according to the President of the Monetary and Financial Committee, Agustin Carstens, this statute does not have solid foundations 
to materialize [22] and according to Nestor Lopez, professor at the Banking and Commercial School, it leaves gaps as the control of the information of illicit activities that still is investigated and of fiscal type, since it does not contemplate the imposition of taxes for crowdfunding activities nor to offer any guarantee to the users who consider it as an investment mechanism [23].

\begin{tabular}{cl}
\hline Country & \multicolumn{1}{c}{ Initiative } \\
\hline Argentina & $\begin{array}{l}\text { Taxes a 15\% net profit in dollars as long } \\
\text { as it is generated outside the country [24]. }\end{array}$ \\
\hline \multirow{3}{*}{ Bolivia } & $\begin{array}{l}\text { The Central Bank of Bolivia issued a pro- } \\
\text { nouncement that expressly prohibits the } \\
\text { circulation of any type of virtual currency } \\
\text { in the country and becomes susceptible to } \\
\text { legal action. }\end{array}$
\end{tabular}

\begin{tabular}{cl}
\hline Brazil & $\begin{array}{l}\text { Creates the Committee for the Regulation } \\
\text { of Digital Currencies, backed by the Cen- } \\
\text { tral [25]. }\end{array}$ \\
\hline Chile & $\begin{array}{l}\text { The Superintendence of Banks and Finan- } \\
\text { cial Institutions have expressed interest in } \\
\text { studying the uses of the Blockchain [26]. }\end{array}$ \\
\hline Colombia & $\begin{array}{l}\text { The Bank of the Republic indicates before } \\
\text { the National Tax and Customs Office the } \\
\text { need to tax the possession of cryptocur- } \\
\text { rencies [27]. }\end{array}$
\end{tabular}

The Fintech Law is approved before the congress whose application and super-

Mexico vision will be in charge of the National Banking and Securities Commission, as well as the Bank of Mexico.

Venezuela $\begin{aligned} & \text { Launches offer of Petro, national crypto- } \\ & \text { currency backed by the Central Bank [28]. }\end{aligned}$

Table 5. Initiatives in some latin american countries regarding the positioning of cryptocurrencies

\section{INTERVENTION OF THE STATE AND THE ROLE OF INTERNATIONAL ORGANIZATIONS}

Cryptocurrency, being one of the greatest technological advances, comes to show once again how hard it is for the system to react towards quick changes and doubts about one of the main supports of society: the need for the economy to be centered on some entity [29]. It should be noted that the international regulation of the financial system is similar to the national regulation by focusing on the following functions: authorizing financial institutions to operate in the respective markets, setting the requirements for the use of information, supervision, sanctions and regulations [30]. The private sector has focused in the functioning of Blockchain, system that generates the data and develops a better digital and financial security, while governments have chosen to debate their legislation because of an illegal use, claimed by them to be the main problem, focusing towards regulation and supervision, they must not try to replace an ideal management of the risks by the private sector [31].

The main obstacles in the application lie in the fact that the regulations apply to only one sector, that means, the regulation is encapsulated, which makes it impossible to regulate since it is a market that does not reside in a specific geographical area, in addition to the reach of the regulation. The international financial system sometimes demands the session of sovereignty actions that are difficult to accept and are separated by rules that are developed in little-known working groups that personify the most developed countries and that have little autonomy with respect to the national authorities. Similarly, the role of cryptocurrencies in the financial market does not go unnoticed by the perception of the main regulatory bodies worldwide in financial matters. Due to the inexistence of an international institution with general competencies in financial regulation, some community institutions stand out: the International Monetary Fund, the G-10, and a forum that regulates the securities markets, that is the International Organization of Securities Commissions.

The IMF position, according to Managing Director Christine Lagarde, establishes that digital currencies do not represent a threat to the balance in the current economy, since they do not represent a high index of volatility and risk. Although these kinds of problems might be resolved in the future and that could even get into trouble the currencies and existing monetary policy [32]. For their part, the committees that make up the G-10 have become the main international forums for the formulation of proposals for financial regulation, mainly through the Basel Committee on Banking Supervision. In the meantime, IOSCO represents the role of a reference institution in matters of international coordination of regulation and supervision of security markets, overseeing the definition and application of rigorous standards of behavior in security markets. 


\section{CONCLUSIONS}

The issue of cryptocurrencies is not so recent considering its course and influence in the global stock market, but the issue regarding its legislation has caused controversy from the moment it raised the possibility with the primary objective of offering user protection through the operation of national systems that provide security in the event of bankruptcy and support in the transactions that are carried out using the Blockchain technology with which cryptocurrency receives more advantages than traditional currency such as irreversibility of operations and decentralization. The many questions this topic asks show a weak and little current facet of financial regulation mainly in Latin American countries since the weak points of these lie in the ability of cryptocurrencies to be a parallel currency, and that most of the countries have a stable economy, where inflation is controlled and the existence of this currency causes confusion.

However, the need to develop management to put on the table all issues related to such regulation, is a matter that shows progress in terms of the implementation of taxes, emission and circulation control and even radical prohibition in some countries. This demonstrates that there is a full understanding of what is happening now and of the effects that ignorance and the ineffective presence of authorities can have. Nevertheless, taking into account current initiatives, little emphasis has been placed on the analysis of the functioning of Blockchain, the technical support of these assets and other applications, the cryptography with which they operate, technique that has been used decades ago to solve privacy and security problems in some Internet platforms. The merit presented by Blockchain lies in the integrity in getting the information without the intervention of third parties and very quickly, which makes it applicable to the link between users around the world in any sector; The inefficiency presented by the current legislation initiatives is due to the application that can take place in a specific space given that this market does not reside in any particular nation, that is why the proposals must focus more on the permission or prohibition, on the adaptation to this investment system, on the control of ledger management and the new functionalities that this might have.

The use of new technologies applied in the economy of a country and its repercussions are not isolated from the world, in the contemporary reality it is essential to have a universal awareness of what is happening, the controversy that has generated the cryptocurrency market is not a subject particularized in an only environment. It has generated international controversy and demonstrates once again how interconnected the global market is, which is not alienated to the particularities of nations, because of this, it is proposed:

1. The creation of an international treaty focused on macroeconomics related to the use and management of cryptocurrencies and the Blockchain technology, in which the interested countries in the affair, can be adhered, propose and incorporate new content that serve other nations.

2. Gradually incorporate the Blockchain technology and train the population through institutes and schools that have experts in the subject and so the society has more knowledge and they can innovate about it. As well as regulate the use and application of cryptocurrencies in each country considering the previous projects, as a consequence if it is regulated, people will have control over them it will be beneficial for all. It is important to note that regulating is not always limiting.

\section{REFERENCES}

[1] M. Daza, J. Topete, A. Davalos, J. Ramirez, J. Ponce, R. Torres, M. Ramirez, "Consideraciones sobre el sistema monetario internacional" in Memorias del V Congreso Internacional de Contaduría Pública: Fiscalización y transparencia, una visión hacia el futuro, Guadalajara, Jal., 2012, (pp. 125-132).

[2] G. Gonzalez, "La criptomoneda y el mercado digital una propuesta de estudio sobre la economía electrónica", Master Thesis, IPN, Mexico City, Mexico, 2012.

[3] M. Castells, "The Information City, the New Economy and the Network Society" in People, Cities and the New Information Economy, London, 2004, pp. 22-37.

[4] E. A. Mora, "Monedas virtuales se suman al comercio internacional" (grade option essay). UNIMILITAR, Bogotá, Col. 2016.

[5] World Federation of Exchanges, "Monthly Reports", [online], 2017. Available: https://www.world-exchanges.org/home/index.php/statistics/monthlyreports

[6] Forex, [online], 2017. Available: https://www.forex. com/en/markets/forex

[7] Coin Market Capitalization, "Cryptocurrency Market Capitalizations”, [online], 2018. Available: https://coinmarketcap.com/ 
[8] F. Kucher, G. Oglietti. (2017, October 12). "Criptomonedas, criptomoda y criptofuturo". Telesur. [Online]. Available: https://www.telesurtv.net/ opinion/Criptomonedascriptomoda-y-criptofuturo-20171012-0054.html

[9] D. Tapscott, A. Tapscott, Blockchain revolution: how the technology behind bitcoin is changing money, business, and the world. Penguin, 2016.

[10] V. Gil. (2018, January 06). "Todos contra el Bitcoin: los gobiernos regulan su uso para tenerlo controlado". La Información. [Online]. Available: https://www.lainformacion.com/economia-negocios-y-finanzas/bitcoin-criptomonedas-gobiernos2018-lucha-terrorismo-blanqueo-capital/6339677

[11] Revista Informatica. (2017). “¿Qué es la encriptación de la informática?”. La Revista Informática. [Online]. Available: http://www.larevistainformatica.com/que-es-encriptacion-informatica.htm

[12] J. Arreola, F. Vallejo Dabdoub. (2017). "Criptomonedas: ¿qué son y porqué importan?”. Forbes. [Online]. Available: https://www.forbes.com. $m x /$ criptomonedas-que-son-y-por-que-importan/

[13] B. Yahari. (2017). "Blockchain y sus aplicaciones". Universidad Católica de Nuestra Señora de la Asunción. [Online]. Available: http://jeuazarru.com/wpcontent/uploads/2017/11/Blockchain.pdf

[14] Statista (2018). "Fintech - Statistics \& Facts". Statista. [Online]. Available: : https://www.statista.com/ topics/2404/fintech/

[15] I. Pollari. "The Rise of Fintech: opportunities and changes". JASSA.

[16] J. Bagley. (2018, February 16). "What is Blockchain Technology? A Step-by-Step Guide For Beginners". Blockgeeks. [Online]. Available: https://blockgeeks. com/guides/what-is-blockchain-technology/

[17] J. Bastardo. (2018, January 16). "China planea más restricciones para el comercio de criptomonedas". Criptonoticias. [Online]. Available: https://www. criptonoticias.com/regulacion/china-planea-masrestricciones-para-el-comercio-de-criptomonedas/

[18] E. Vera. (2018, February 15). "Comisión de Comercio Norteamericana pide autorregulación a las compañías de criptomonedas". Criptonoticias. [Online]. Available: https://www.criptonoticias.com/regulacion/comision-comercio-norteamericana-pideautorregulacion-companias-criptomonedas/

[19] A. Noguera. (2017, December 12). "Gobierno de Francia permitirá la negociación de valores no cotizados con Blockchain". Infocoin. [Online]. Available: http://infocoin.net/2017/12/12/gobierno-de-francia-permitira-la-negociacion-de-blockchain-de-valores-no-cotizados/
[20] Diario TI. (2018, January 19). "Francia y Alemania propondrán regulación del Bitcoin". DiarioTI.com. [Online]. Available: https://diarioti.com/ francia-y-alemania-propondranregulacion-de-bitcoin/106584

[21] F. Gutierrez. (2018, February 21). "Ley Fintech avanza en Diputados pese a ser muy general”. El Economista.[Online]. Available: https://www. eleconomista.com.mx/sectorfinanciero/Ley-Fintech-avanza-en-Diputados-pese-a-ser-muy-general-20180221-0130.html

[22] G. López.(2017, July 03). "Ley Fintech y Bitcoin para América Latina serán discutidos en México mañana". Diario Bitcoin. [Online]. Available: http:// www.diariobitcoin.com/index.php/2017/07/03/ ley-fintech-y-bitcoin-para-america-latina-serandiscutidos-en-mexico-manana/

[23] V. Mendoza. (2018, January 22). "Ya tenemos Ley Fintech, pero con vacíos en lavado y fraude". Forbes. [Online]. Available: https://www.forbes. com.mx/ya-hay-ley-fintech-pero-con-vacios-enlavado-y-fraude/

[24] Redacción LA. (2017, December 17). "Impuesto al bitcoin: el Gobierno apunta a captar parte de sus ganancias". Los Andes. [Online]. Available: http:// losandes.com.ar/article/view?slug=impuesto-albitcoin-el-gobierno-apunta-a-captar-parte-de-susganancias

[25] D. Aguilar. (2017, May 31). "Cámara de Diputados de Brasil crea Comité de Regulación de Monedas Digitales". Criptonoticias. [Online]. Available: https://www.criptonoticias.com/regulacion/camaradiputados-brasil-crea-comite-regulacion-monedasdigitales/

[26] C. Ramírez. (2017, July 02). "El avance de las monedas virtuales en Chile: cuatro empresas transan más de US\$ 7 millones mensuales y suman casi 20 mil clientes". El Mercurio. [Online]. Available: https://www.pwc.com/cl/es/prensa/prensa/2017/ El-avance-de-las-monedas-virtuales-en-Chilecuatro-empresas-transan-mas-de-US-7-millonesmensuales-y-suman-casi-20-mil-clientes.html

[27] E. Vera. (2018, February 14). "Gerente del Banco de la República de Colombia espera pago de impuestos por posesión de Bitcoins". Criptonoticias.[Online]. Available: https://www.criptonoticias.com/regulacion/gerente-banco-republica-colombia-esperapago-impuestos-posesion-bitcoins/

[28] M. Vega. (2018, January 31). "Venezuela tasa en 60 dólares el valor de su moneda virtual: preventa iniciaría en febrero". Biobiochile.cl. [Online]. Available: http://www.biobiochile.cl/noticias/internacional/america-latina/2018/01/31/venezuelatasa-en-60-dolares-el-valor-de-su-moneda-virtualpreventa-iniciaria-en-febrero.shtml 
[29] M. Puigvert. (2016, May 27). "Latinoamérica se queda atrás en materia de regulación de monedas". Criptonoticias. [Online]. Available: https://www. criptonoticias.com/opinion/latinoamerica-quedaatras-materia-regulacion-criptomonedas/

[30] A. Sanz. (2002, August- September). “¿Quién regula el sistema financiero internacional? Foros y Normas". Revistas ICE. [Online]. Available: http:// www.revistasice.com/CachePDF/ICE_801_145164_8917E65CB20CE27570171F665B7B0560.pdf
[31] J. Caruana. (2008). "Regulación e innovación en la reciente crisis financiera". Revista Estabilidad Financiera. [Online]. Available: https://www.bde. es/f/webbde/Secciones/Publicaciones/InformesBoletinesRevistas/RevistaEstabilidadFinanciera/08/ May/Fic/IEF200814-1.pdf

[32] Bloomberg. (2017, September 29). "FMI pide no ignorar al Bitcoin". El Financiero. [Online]. Available: http://www.elfinanciero.com.mx/mercados/ fmi-pide-no-ignorar-al-bitcoin.html 